\title{
PI3K-delta Inhibitor PWT143
}

National Cancer Institute

\section{Source}

National Cancer Institute. PI3K-delta Inhibitor PWT 143. NCI Thesaurus. Code C123925.

An orally bioavailable inhibitor of the delta isoform of phosphatidylinositide 3-kinase (PI3K), with potential antineoplastic activity. Upon oral administration, PI3K-delta inhibitor ME-401 selectively inhibits the delta isoform of PI3K and prevents the activation of the PI3K/AKT signaling pathway. This both decreases proliferation and induces cell death in PI3K-delta-overexpressing tumor cells. PI3K-delta plays a key role in the proliferation and survival of hematologic cancer cells. The targeted inhibition of PI3K-delta is designed to preserve PI3K signaling in normal, non-neoplastic cells. PI3K, an enzyme often overexpressed in cancer cells, plays a crucial role in tumor cell regulation and survival. 